\title{
Somatic cell count and milk yield on physicochemical components of milk from free-stall housed cows
}

\author{
Contagem de células somáticas e produção leiteira sobre \\ constituintes físico-químicos do leite de vacas confinadas
}

\author{
José Antônio de Freitas ${ }^{1}$; Janielen da Silva'; \\ Américo Fróes Garcez Neto ${ }^{1 *}$; Tiago Machado dos Santos ${ }^{3}$
}

\begin{abstract}
Measurement and evaluation of the factors that may influence milk composition has been shown to determine the actual gains in milk quality and quantity. The study was conducted to evaluate the influence of daily milk yield on the physicochemical composition of milk and analyze the correlations between milk yield and somatic cell count (SCC) on the fat, protein, lactose, total solids and nitrogen urea contents in Holstein cows' milk. A total of 3,544 data collected from 467 cows were evaluated. In the analysis, the animals were divided into groups - I (5-15 $\mathrm{kg}$ milk day $\left.^{-1}\right)$, II (15-30 kg milk day $\left.{ }^{-1}\right)$ and III (above $30 \mathrm{~kg}$ milk day $\left.{ }^{-1}\right)$ - based on their daily production. Animals of Group I had higher SCC (P< 0.05 ) and fat and protein percentage when compared with Group III. However, the lactose content was lower $(\mathrm{P}<0.05)$ than Group II and III. No correlation $(\mathrm{P}>0.05)$ between SCC and fat, protein and total solids contents was observed. A lower milk yield is significantly associated with a higher SCC, which, besides hindering the quality of milk, compromises the cow's udder health.
\end{abstract}

Key words: Fat. Lactose. Protein. Total solids. Urea.

\section{Resumo}

Quantificar e qualificar os fatores que podem influenciar a composição do leite tem sido de extrema importância para ganhos tanto em quantidade como em qualidade no leite produzido. O estudo foi realizado visando avaliar a influência da produção leiteira sobre a composição físico-química do leite e analisar as correlações entre a produção leiteira e a contagem de células somáticas (CCS) sobre os teores de gordura, proteína, lactose, sólidos totais e nitrogênio uréico no leite de vacas Holandesas. 3.544 dados referentes a 467 vacas foram avaliados. Na análise, os animais foram distribuídos em grupos I ( 5 a $15 \mathrm{~kg}$ leite dia $\left.{ }^{-1}\right)$, II (15 a $30 \mathrm{~kg}$ leite dia ${ }^{-1}$ e III (acima de $30 \mathrm{~kg}$ leite dia $\left.{ }^{-1}\right)$, de acordo com sua produção diária. Animais do grupo I apresentaram maior $(\mathrm{P}<0,05) \mathrm{CCS}$, porcentagem de gordura e proteína quando comparados ao grupo III, porém, menor $(\mathrm{P}<0,05)$ teor de lactose quando comparados aos grupos II e III. Não foi observada correlação $(\mathrm{P}>0,05)$ entre a CCS e o teor de gordura, proteína e sólidos totais. Menores produções leiteiras estão significativamente associadas à alta CCS, o que por sua vez, além de trazer prejuízos também significativos à qualidade do leite produzido, compromete o estado sanitário do úbere das vacas.

Palavra-chave: Gordura. Lactose. Proteína. Sólidos totais. Ureia.

\footnotetext{
${ }^{1}$ Profs., Departamento de Zootecnia, Universidade Federal do Paraná, UFPR, Palotina, PR, Brasil. E-mail: americo.garcez@ufpr. br; freitasjaf@ufpr.br

${ }^{2}$ M.e em Ciência Animal e Pastagens, Escola Superior de Agricultura Luiz de Queiroz, Universidade de São Paulo, ESALQ/USP, Piracicaba, SP, Brasil. E-mail: janielen@hotmail.com

${ }^{3}$ M.e em Ciência Animal, UFPR, Palotina, PR, Brasil. E-mail: tiagom.santos15@gmail.com

* Author for correspondence
} 


\section{Introduction}

The milk production chain is increasingly competitive and this has stimulated the search for quality milk products. In Brazil, the main focus is on the quality of raw materials, process control and quality maintenance (LIMA et al., 2006). Therefore, quantifying and qualifying the factors that may influence the milk composition have been extremely important to increasing both the quantity and quality of the produced milk.

The physicochemical composition of milk varies depending on many factors, particularly breed, nutrition, lactation period, age and physiology of the animal, weather conditions and amount of produced milk (MAGALHÃES et al., 2006; SOUZA et al., 2010). In addition, the pathological processes of the mammary gland, such as mastitis, can cause significant changes in the milk quality and it is one of the factors that most contributes to economic losses in the milk production chain. Indeed, mastitis can reduce the milk production by up to $50 \%$ (BUENO et al., 2005; LADEIRA, 2007; REIS et al., 2007).

The milk constituents and, consequently, its nutritional quality, may change during mastitis by direct action of the microorganisms of contagious and environmental origin, or their enzymes, the change in vascular permeability of the mammary gland and the reduction in synthesis capability of the secretory tissue (MACHADO et al., 2000; ZAFALON et al., 2005).

When mastitis occurs, although milk is visually normal, it has a high somatic cell count (SCC) and a change in its natural composition, such as increased levels of serum proteins (ZHANG et al., 2015), and a decrease in the casein, lactose, total solids and fat contents. These changes depend on the degree of infection and the stage of the disease in the animal (PEREIRA et al., 1997; SILVA et al., 2010; COELHO et al., 2012; GUARIGLIA et al., 2015). A high SCC caused by mastitis may also favor the disposal of the milk because the presence of antibiotics residues increase the production costs and, consequently, reduce the productive life of the animal (CUNHA et al., 2008; OLIVEIRA et al., 2010).

The mammary gland infectious process may result in milk production losses of up to $25 \%$ of the total production. Besides negatively affecting the production of milk and its nutritional value,

Thus, this work evaluated the influence of average daily milk production on the milk constituents (protein, fat, lactose, total solids, urea nitrogen and SCC) and analyzed the correlation between milk production and SCC on the constituents of milk in Holstein cows kept in total confinement.

\section{Material and Methods}

The data were collected at Star Milk - Fazenda Iguaçu, Céu Azul, PR, Brazil (latitude: 2502'43”S;

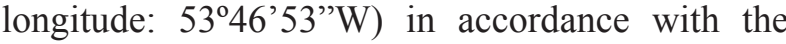
Ethical Principles in Animal Testing adopted by the Colégio Brasileiro de Experimentação (COBEA, Brazilian Testing Association). According to the Köppen-Geiger climate classification, the property is located in a temperate climate $(\mathrm{Cfb})$.

The herd consisted of 700 purebred Holstein cows, kept in total confinement (free-stall) and mechanically milked three times a day. Milk with an SCC above 750,000 was discarded to avoid compromising the tank average count, which was 250,000 . The pre-dipping sanitary management was based on cleaning the udders with potable water and drying with paper towels (one sheet of paper for each udder). The post-dipping management was performed by immersion of the udders in commercial $10 \%$ glycerin iodine solution. All the sanitary management was standardized, considering the cows in the study. The animals used in the study were fed a $17 \%$ crude protein diet (dry matter basis), based on corn silage, pre-dried oats, corn, soybean meal, cottonseed meal and a mineral and vitamin premix. This was the only diet provided to the animals and it was available ad libitum so that 
the consumption was determined by the needs of the animal. Thus, higher production animals had higher dry matter consumption. According to the differences in the milk production, the animals were divided into homogeneous batches to facilitate nutritional management.

Throughout 2006, a total of 3,544 data regarding the daily average milk production $\left(\mathrm{kg} \mathrm{day}^{-1}\right)$ and milk composition (fat, protein, lactose, total solids, urea nitrogen and SCC) of 467 cows were analyzed and the information simultaneously transferred to a herd control software (Agenda 3, Piracicaba, Brazil). The average milk production of the animals used in the study was $28.60 \mathrm{~kg}$ day $^{-1}$. The cows were randomly selected from the first- to the third-order of lactation, with an average lactation period of 305 days. The milk sample collection and control was performed monthly in every animal. The samples were stored in sterile plastic vials containing bronopol (2-bromo-2-nitro-1,3-propanediol) and identified with the animal code. Iced isothermal boxes (2$6^{\circ} \mathrm{C}$ ) were used to preserve the samples, which were sent to the laboratory of the Associação Paranaense dos Criadores de Bovinos da Raça Holandesa (APCGRH, Paraná Association of Holstein Cattle Breeders) for the analysis of composition (protein, fat, lactose and total solids), urea nitrogen (infrared method - PO ANA 009) and SCC (flow cytometry - PO ANA 008). Based on the results, they were transferred to the herd control software where they were stored. Each entry consisted of the following information: animal code, average daily milk production, analysis of milk components (protein, fat, lactose and total solids), urea nitrogen and SCC.

For the database analysis procedures, the animals were divided into Group I (5-15 kg day $\left.{ }^{-1}\right)$, II (15-30 $\mathrm{kg}$ day $^{-1}$ ) and III (above $30 \mathrm{~kg} \mathrm{day}^{-1}$ ), according to the average daily milk production for the evaluation period. A completely randomized design was used to compare between the groups, with groups as treatments and the animals within each group as replicates.
The obtained data were compared by using analysis of variance (ANOVA) followed by StudentNewman-Keuls comparison of means test at 5\% probability. Statistical procedures were performed using Statistical Analysis System (SAS, 2002). In addition to the comparison of means between treatments, correlation analysis of the variables was performed.

\section{Results and Discussion}

Table 1 shows the fat, protein, lactose, total solids, urea nitrogen contents and SCC of the animals with a milk production of 5-15 $\mathrm{kg}$ day $^{-1}$ (Group I), 15$30 \mathrm{~kg} \mathrm{day}^{-1}$ (Group II) and over $30 \mathrm{~kg} \mathrm{day}^{-1}$ (Group III). Among the groups, it is observed that the group with higher milk production (Group III) showed lower levels of fat and protein and higher levels of lactose. The urea nitrogen did not differ among the groups, but the SCC was higher for the group with the lower milk production (Group I). Conversely, based on the total solids results, it is not possible to clearly differentiate the milk production ranges.

Regarding the fat and SCC, the animals belonging to the group with lower milk production (Group I) had the highest SCC and the highest fat percentage when compared to the higher productivity group (Table 1). When there is an infection in the mammary gland, there may be a reduction in milk production due to the damage to the mammary epithelial cells, reduced synthesis of lactose or obstruction of the ducts by microorganisms. This reduction in milk production can lead to the concentration of certain constituents, such as fat, as occurred in this experiment. Machado et al. (2000) reported an increase in the fat percentage in tanks with higher SCC, with a significant increase in the concentration of fat in tanks with over 1,000,000 cells $\mathrm{mL}^{-1}$. Guariglia et al. (2015) also found a higher fat concentration combined with greater SCC. According to the authors, this finding is a result of the reduction in milk production due to the $\mathrm{SCC}$, with a resultant concentration of this component. 
Table 1. Fat, protein, lactose, total solids, urea nitrogen contents and somatic cell count (SCC) of animals with a milk production of 5-15 kg day-1 (Group I), 15-30 kg per day-1 (Group II) and over $30 \mathrm{~kg} \mathrm{day}^{-1}$ (Group III).

\begin{tabular}{lccc}
\hline Constituents & Group I & Group II & Group III \\
\hline Fat (\%) & $3.68 \mathrm{a}$ & $3.65 \mathrm{a}$ & $3.35 \mathrm{~b}$ \\
Protein (\%) & $3.36 \mathrm{a}$ & $3.25 \mathrm{~b}$ & $3.07 \mathrm{c}$ \\
Lactose (\%) & $4.06 \mathrm{c}$ & $4.42 \mathrm{~b}$ & $4.53 \mathrm{a}$ \\
Total solids (\%) & $12.15 \mathrm{ab}$ & $12.27 \mathrm{a}$ & $11.87 \mathrm{~b}$ \\
Urea nitrogen (\%) & $11.64 \mathrm{a}$ & $12.33 \mathrm{a}$ & $12.65 \mathrm{a}$ \\
SCC (cells $\left.\mathrm{mL}^{-1}\right) \times 1000$ & $792.5 \mathrm{a}$ & $449.8 \mathrm{~b}$ & $375.5 \mathrm{~b}$ \\
\hline
\end{tabular}

Means followed by the same lowecase letters in a row are not statistically different by Student-Newman-Keuls test at $5 \%$ probability.

According to the literature, factors other than a lower or higher milk production can also influence the milk fat content. Rosa et al. (2012) found that the fat concentration in milk is greatly influenced by genetics, lactation period, calving season, calving order, nutrition, health, breed and age of the animal. Nutritional factors also exert great influence on this parameter, mainly due to the genetic improvement.

The correlation between SCC and the fat percentage was not significant (Table 2). This result can be explained by the SCC average found in the studied herd (Table 3), which can be considered low. Consequently, it was not sufficient to change the milk fat content. These results corroborate the study of Pereira et al. (1999), who mentioned that changes in fat concentrations, in many cases, only occur when an infection in the mammary gland becomes severe. Namely, the animal must have high SCCs to change the fat concentration.

Regarding the fat content, Group I had a significantly higher protein content $(\mathrm{P}<0.05)$ than Groups II and III. This can also be explained by the concentration effect, resulting from a relatively higher SCC and, subsequently, reduced milk production. A positive but non-significant correlation existed between the SCC and the protein content. As explained above, the reduction in milk production caused by intramammary infection can result from various factors and this reduction leads to the concentrations of milk constituents, in this instance, protein. In contrast, the lack of significant correlation between the SCC and the protein can be explained by the reduction in casein levels but a simultaneous increase in plasma proteins due to the increased vascular permeability during mastitis.

The increase in vascular permeability during mastitis causes transfer of the plasma proteins to the mammary gland to combat the infection process, resulting in a higher protein concentration. However, this increase is not positive to milk quality as the principal protein in milk, casein, is reduced during mastitis, particularly by the action of bacteria-derived proteases, leukocytes and blood (KITCHEN, 1981; PEREIRA et al., 1997). According to Auldist and Hubble (1998), due to the reduction in casein synthesis and a simultaneous increase in serum milk proteins, there is no consensus in the literature regarding the increase in the total protein percentage in the milk of animals with high SCC. In a recent study, Zhang et al. (2015) tried to understand the changes in the quality of milk with different SCC levels $\left(10^{5}\right.$ to $10^{6}$ cells $\left.\mathrm{mL}^{-1}\right)$. They discovered that milk samples with higher SCC have higher concentrations of proteins with immunological function (cathelicidins, prostaglandins and immunoglobulins). Additionally, the authors showed that milk with a higher SCC had higher concentrations of protease inhibitors, suggesting a greater activation of defenses against microorganisms in these mammary glands. 
Table 2. Analysis of correlation (r) between somatic cell count (SCC) and milk production on the fat, protein, lactose, total solids and urea nitrogen contents in Holstein cows kept in total confinement.

\begin{tabular}{|c|c|c|}
\hline & \multicolumn{2}{|c|}{ SCC $\left(\right.$ cells $\left.\mathrm{mL}^{-1}\right) \times 1000$} \\
\hline Component & Coefficient of correlation & Significance level \\
\hline Fat $(\%)$ & 0.09046 & 0.0929 \\
\hline Protein $(\%)$ & 0.08100 & 0.1310 \\
\hline Lactose $(\%)$ & -0.28315 & $<0.0001$ \\
\hline Total solids $(\%)$ & 0.00482 & 0.9287 \\
\hline Urea nitrogen $(\%)$ & -0.12843 & $<0.0187$ \\
\hline \multirow[t]{2}{*}{ Milk production $\left(\mathrm{kg} \mathrm{cow}^{-1} \mathrm{day}^{-1}\right)$} & -0.18116 & 0.0007 \\
\hline & \multicolumn{2}{|c|}{ Milk production $\left(\mathrm{kg} \mathrm{cow}^{-1}\right.$ day $\left.^{-1}\right)$} \\
\hline Component & Coefficient of correlation & Significance level \\
\hline Fat $(\%)$ & -0.16943 & 0.0014 \\
\hline Protein $(\%)$ & -0.37156 & $<0.0001$ \\
\hline Lactose $(\%)$ & 0.39230 & $<0.0001$ \\
\hline Total solids $(\%)$ & -0.15436 & 0.0037 \\
\hline Urea nitrogen $(\%)$ & 0.12429 & 0.0219 \\
\hline $\mathrm{SCC}\left(\right.$ cells $\left.\mathrm{mL}^{-1}\right) \times 1000$ & -0.18116 & 0.0007 \\
\hline
\end{tabular}

Table 3. Mean, standard error of the mean and coefficient of variation of the analyzed variables in Holstein cows' milk.

\begin{tabular}{|c|c|c|c|}
\hline Variable & Mean & SEM & CV (\%) \\
\hline Milk production $\left(\mathrm{kg} \mathrm{cow}^{-1}\right.$ day $\left.^{-1}\right)$ & 28.60 & 0.59 & 39.44 \\
\hline Fat $(\%)$ & 3.51 & 0.05 & 25.64 \\
\hline Protein $(\%)$ & 3.18 & 0.01 & 9.43 \\
\hline Total solids (\%) & 12.07 & 0.06 & 9.11 \\
\hline $\mathrm{SCC}\left(\right.$ cells $\left.\mathrm{mL}^{-1}\right) \times 1000$ & 461.18 & 38.69 & 158.31 \\
\hline Urea nitrogen $(\%)$ & 12.37 & 0.17 & 26.68 \\
\hline Lactose $(\%)$ & 4.42 & 0.02 & 8.37 \\
\hline
\end{tabular}

SEM: standard error of the mean; CV: coefficient of variation; MP: milk production; SCC: somatic cell count.

It was observed that the animals belonging to Group II had a higher total solids content than the animals in Group III. Considering that the main components of total solids are fat, protein and lactose, the higher concentration of total solids presented by Group II can be explained by the higher content of both fat and protein $(\mathrm{P}<0.05)$ in this group compared to Group III (Table 1). According to Ribas et al. (2004), fat, protein and lactose account for 30, 26 and 37\%, respectively, of the total solids of the milk composition. Galvão Júnior et al. (2010), while evaluating the effect of the daily milk production on its physicochemical composition, observed that milk from animals producing up to $10 \mathrm{~kg} \mathrm{day}^{-1}$ had higher $(\mathrm{P}<0.05)$ total solids and protein content than that from animals producing more than $15 \mathrm{~kg}$ day $^{-1}$.

There was no significant correlation $(\mathrm{P}>0.05)$ between SCC and the total solids content and this can be explained by the non-significant changes in protein and fat, the major constituents of the total solids. The only significant change found was in the lactose content (Table 2). The correlations found in this study between total solids and these three components were higher for the fat content $(r=0.87413)$, followed by protein $(r=0.53939)$, whereas the lowest correlation was for the lactose content $(r=0.15320)$. Bueno et al. (2005) analyzed 
18,949 milk samples and observed a negative correlation between the SCC and the total solids content. The authors attributed this reduction to changes in the protein and lactose content, which also presented a negative correlation in their study. Ribas et al. (2004), in a study with tank milk samples from 32,590 herds in the states of Paraná, Santa Catarina and São Paulo, found that the correlations between total solids and fat, protein and lactose, were respectively $r=0.875,0.653$ and 0.237 .

The animals belonging to Group I had higher ( $\mathrm{P}$ $<0.05)$ SCC and the lowest $(\mathrm{P}<0.05)$ lactose content when compared to the other groups (Table 1). The significant negative correlation found between SCC and lactose content $(\mathrm{r}=-0.28315)$ corroborates this result, namely, the higher the SCC, the lower the lactose content. Pereira et al. (1997) explained the reduction in the lactose content by the lower synthesis of this component, due to the destruction of secretory tissue in infected mammary glands or milk lactose transfer to the blood due to the increase in membrane permeability. This confirmed the findings published by Shuster et al. (1991), who found high concentrations of lactose in the blood and urine of cows with mastitis. The reduction in lactose content can also be explained by the use of lactose by intramammary pathogens for multiplication or in cases where the swelling of the mammary gland limits the glucose intake, further reducing the lactose production (KITCHEN, 1981). Indeed, Kitchen (1981) suggested that the lactose concentration in milk could be used as a criterion for detecting mastitis in the dairy herd.

As in this study, other studies have found a reduction in milk lactose content with an increase in SCC. For example, Silva et al. (2012) found that milk and whey samples with higher SCC levels also had lower levels of lactose. Machado et al. (2000), analyzing 4,785 data, obtained similar results where the higher SCC milk tank had lower lactose percentages, with a significant reduction of over 500,000 cells $\mathrm{mL}^{-1}$. In a study on milk samples, Reis et al. (2007) also found a negative correlation between SCC and the percentage of lactose ( $\mathrm{r}=$ $-0.4023)$. One of the major losses for the cattle breeders in dairy herds with mastitis is the reduction of milk production. The lowest lactose percentage during mastitis contributes to this reduction because lactose is the component of milk with greater osmotic capacity (AULDIST; HUBBLE, 1998).

Although not significant $(\mathrm{P}>0.05)$, it was observed that animals with a higher SCC (Group I) had a lower urea nitrogen percentage when compared to the other groups. Conversely, a negative $(\mathrm{r}=-0.12843)$ but significant $(\mathrm{P}<0.05)$ correlation between SCC and urea nitrogen content in milk was evident, namely, as the SCC increased, the urea nitrogen concentration decreased. A similar result was found by Meyer et al. (2006), who found that when transforming the SCC to natural $\log$ (LSCC), a $0.29 \mathrm{mg} \mathrm{dL}^{-1}$ reduction in the urea nitrogen concentration of milk for each one unit increase in LSCC was evident. Godden et al. (2001) also found a negative correlation between the linear SCC and the urea nitrogen concentration in milk. However, Botaro et al. (2011), collected 49 commercial dairy herds milk samples on a monthly basis but did not found any correlation between SCC and nonprotein nitrogen concentration in milk. Mastitis can influence the urea nitrogen concentration in the milk from infected mammary glands, as a result of changes in the permeability of cell membranes, which is a consequence of the inflammatory process (SANTOS; FONSECA, 2006).

It was verified that Group I, with lower milk production, presented significantly higher SCC $(\mathrm{P}<0.05)$ than Group II and III (Table 1). One of the factors that contributes to the decrease in milk production is the increase in the SCC (ZANELA et al., 2006), which may be proven by the negative ( $\mathrm{r}$ $=-0.18116)$ and significant $(\mathrm{P}<0.05)$ correlation found between these two variables in this study (Table 2). Cunha et al. (2008), in a study with Holstein bovine milk, also found a negative correlation between SCC and milk production ( $\mathrm{r}$ $=-0.1837)$. Similarly, this also verified by Pereira 
et al. (2001) who, while converting the linear SCC score, observed a negative effect on milk production associated with an increase in only one linear score unit, corresponding to a reduction of $315 \mathrm{~kg}$ of milk per animal in 305 days of lactation. Based on Auldist and Hubble (1998), the lowest milk production is due to the epithelial cells injury during mastitis, causing reduced synthesis and secretion by the mammary gland. Moreover, in subclinical infections, microorganisms can block the mammary ducts, hindering the milk flow.

In this study, the animals of Group I presented (P $<0.05)$ higher fat concentration when compared to Group III, and higher $(\mathrm{P}<0.05)$ protein concentration than Groups II and III. Animals from Group II had higher $(\mathrm{P}<0.05)$ fat and protein content than those from Group III. A comparable result was found by Galvão Júnior et al. (2010) in a study with Zebu cattle breeds, in which the animals were divided into three groups according to the average daily production. The authors observed that the protein and fat concentrations tended to be lower as the milk production in the various study groups increased. Pereda et al. (2005) mentioned that in general, the fat and protein content are inversely proportional to the amount of produced milk, which explains the positive and significant correlation $(\mathrm{P}<0.05)$ obtained in this study between the fat percentage and milk production $(\mathrm{r}=-0.16943)$ and between the protein percentage and milk production ( $\mathrm{r}=-0.37156)$ (Table 2). Cunha et al. (2008), working with Holstein cows, also observed negative correlations between milk production and fat $(\mathrm{r}=$ $-0.2917)$ and protein $(r=-0.3449)$ percentages.

In relation to the urea nitrogen concentration in milk of the various groups, there was no significant difference (Table 1). Even with the homogeneity obtained in the separation of animals by milk production ranges, the milk production of animals belonging to the same range still varied. It may compromise the occurrence of significant differences among various groups, particularly when it comes to a smaller number of production groups. Despite the absence of significant differences among the groups, when the animals are individually compared, the correlation analysis between the milk and the urea nitrogen concentration is positive and significant (Table 2), namely, the urea nitrogen percentage increased as the milk production increased. Meyer et al. (2006) analyzed 7,006 milk samples and verified that the average daily milk production was the variable that most influenced the milk urea nitrogen (MUN) concentration. For every additional kilogram in daily milk production, there was an increase of $0.1054 \mathrm{mg} \mathrm{dL}^{-1}$ in the MUN concentration. Galvão Júnior et al. (2010) found the following minimum and maximum values, respectively, for three different groups classified based on their milk production: 6.30 and 21.90 $\mathrm{mg} \mathrm{dL}{ }^{-1}$ for Group I (milk production of $10 \mathrm{~kg}$ day $^{-1}$ ), 8.05 and $31.20 \mathrm{mg} \mathrm{dL}^{-1}$ for Group II (milk production of $10.1-15 \mathrm{~kg} \mathrm{day}^{-1}$ ) and 4.90 and 17.50 $\mathrm{mg} \mathrm{dL}^{-1}$ for Group III (milk production of over $15 \mathrm{~kg}$ day $^{-1}$ ). Oltner and Wiktorsson (1983) stated that the increase in the MUN concentration as a result of a higher milk production is due to the high correlation between milk production and the protein-to-energy ratio in the diet.

In the lactose evaluations, the highest average was found for Group III (4.53\%), followed by Group II (4.42\%), while the lowest average was found for Group I (4.06\%). Namely, the groups with higher milk production presented the highest lactose content (Table 1). This result concurs with Zanela et al. (2006), who analyzed the milk yield and quality of production systems in the southern region of Rio Grande do Sul and observed that the animals with higher milk production, belonging to the specialized system, had the highest lactose percentage (4.49\%) compared to the semi-specialized $(4.39 \%)$ and the non-specialized (4.32\%) systems. According to Auldist and Hubble (1998), the lactose concentration in the milk cannot be changed by nutritional factors, indicating that its levels are directly associated with the osmotic function and milk production in the mammary gland. More specifically, the lactose 
content tends to increase with the lactation peak and, consequently, to decrease by the end of the lactation. Hence, the positive $(r=0.39230)$ and significant $(P$ $<0.05$ ) correlation between the milk production and the lactose percentage corroborates the literature results (Table 2). Similarly, Gonzalez et al. (2006) analyzed 10 dairy production units belonging to the Pelotas' dairy region and observed a positive correlation between the lactose percentage and milk production.

In a study on the economic effects of bovine mastitis, Halasa et al. (2007) affirmed that the reduction of milk quality is one of the factors responsible for the losses in processing and quality of dairy products. The authors note that once there are many variations in milk constituents in cases of mastitis, it is very difficult to estimate the economic losses of the cattle breeder. The only changes in the milk quality which have a direct effect and can be forecasted are the factors that are part of the milk payment system, for example, total bacterial count (TBC) and SCC.

\section{Conclusion}

The results obtained in this study indicate that a high milk production reduces the fat, protein and total solids content due to the dilution effect of these constituents and increases the lactose percentage. Moreover, the increase in SCC, an effect of mastitis on the herd, results in the reduction of milk production and deteriorates the quality characteristics of the produced milk, such as decreasing the lactose content, which shows the importance of measures to control and prevent this disease in the herd.

Other milk qualitative parameters, such as fat and protein concentration, do not reflect the actual health of the mammary gland because an increase in the levels of these constituents may result from reduced milk production.

\section{Acknowledgement}

The authors thank Star Milk - Fazenda Iguaçu, Paraná, for supporting the collection and availability of the data used in this study.

\section{References}

AULDIST, M. J.; HUBBLE, I. B. Effects of mastitis on raw milk and dairy products. Australian Journal of Dairy Technology, Melbourne, v. 53, n. 1, p. 28-36, 1998.

BOTARO, B. G.; CORTINHAS, C. S.; MESTIERI, L.; MACHADO, P. F.; SANTOS, M. V. Composição e frações proteicas do leite de rebanhos bovinos comerciais. Veterinária e Zootecnia, Botucatu, v. 18, n. 1, p. 81-91, 2011.

BUENO, V. F. F.; MESQUITA, A. J.; NICOLAU, E. S.; OLIVEIRA, A. N.; OLIVEIRA, J. P.; NEVES, R. B. S.; MANSUR, J. R. G.; THOMAZ, L. W. Contagem celular somática: relação com a composição centesimal do leite e período do ano no Estado de Goiás. Ciência Rural, Santa Maria, v. 35, n. 4, p. 848-854, 2005.

COELHO, K. O.; MESQUITA, A. J.; MACHADO, P. F.; OLIVEIRA, A. N.; SOUZA, C. M.; MEYER, P. M. Níveis de células somáticas sobre a proteólise do queijo Mussarela. Revista Brasileira de Saúde e Produção Animal, Salvador, v. 13, n. 3, p. 682-693, 2012.

CUNHA, R. P. L.; MOLINA, L. R.; CARVALHO, A. U.; FACURY FILHO, E. J.; FERREIRA, P. M.; GENTILINI, M. B. Mastite subclínica e relação da contagem de células somáticas com número de lactações, produção e composição química do leite em vacas da raça Holandesa. Arquivos Brasileiros de Medicina Veterinária e Zootecnia, Belo Horizonte, v. 60, n. 1, p. 19-24, 2008.

GALVÃO JÚNIOR, J. G. B.; RANGEL, A. H. N.; MEDEIROS, H. R.; SILVA, J. B. A.; AGUIAR, E. M.; MADRUGA, R. C.; LIMA JÚNIOR, D. M. Efeito da produção diária e da ordem de parto na composição físico-química do leite de vacas de raças zebuínas. Acta Veterinária Brasilica, Mossoró, v. 4, n. 1, p. 25-30, 2010.

GODDEN, S. M.; LISSEMORE, K. D.; KELTON, D. F.; LESLIE, K. E.; WALTON, J. S.; LUMSDEN, J. H. Relationships between milk urea concentrations and nutritional management, production, and economic variables in Ontario dairy herds. Journal of Dairy Science, Champaign, v. 84, n. 5, p. 1128-1139, 2001.

GONZALEZ, H. L.; FISCHER, V.; RIBEIRO, M. E. R.; STUMPF JUNIOR, W.; GOMES, J. F.; FAGUNDES, C. M.; SILVA, M. A. Comparação da qualidade do leite em diferentes sistemas de produção da bacia leiteira de 
Petolas, RS. Revista Brasileira de Agrociência, Pelotas, v. 12, n. 4, p. 475-482, 2006.

GUARIGLIA, B. A. D.; SANTOS, P. A.; ARAÚJO, L. S.; GIOVANNINI, C. I.; NEVES, R. B. S.; NICOLAU, E. S.; SILVA, M. A. P. Effect of the somatic cell count on physicochemical components of milk from crossbred cows. African Journal of Biotechnology, Nairobi Kenya, v. 14, n. 17, p. 1519-1524, 2015.

HALASA, T.; HUIJPS, K.; ØSTERÅS, O.; HOGEVEEN, $\mathrm{H}$. Economic effects of bovine mastitis and mastitis management: a review. Veterinary Quarterly, The Hague, v. 29, n. 1, p. 18-31, 2007.

KITCHEN, B. J. Bovine mastitis: milk compositional changes and related diagnostic tests. Journal of Dairy Research, Cambridge, v. 48, n. 1, p. 167-88, 1981.

LADEIRA, S. R. L. Mastite bovina. In: RIET-CORREA, F.; SCHILD, A. L.; LEMOS, R. A. A.; BORGES, J. R. J. (Ed.). Doenças de ruminantes e equídeos. 3. ed. Santa Maria: Editora Pallotti, 2007. p. 359-371.

LIMA, M. C. G.; SENA, M. J.; MOTA, R. A.; MENDES, E. S.; ALMEIDA, C. C.; SILVA, R. P. P. E. Contagem de células somáticas $\mathrm{e}$ análises físico-químicas $\mathrm{e}$ microbiológicas do leite cru tipo c produzido na Região Agreste do Estado de Pernambuco. Arquivos do Instituto Biológico, São Paulo, v. 73, n. 1, p. 89-95, 2006.

MACHADO, P. F.; PEREIRA, A. R.; SARRÍES, G. A. Composição do leite de tanques de rebanhos brasileiros distribuídos segundo sua contagem de células somáticas. Revista Brasileira de Zootecnia, Viçosa, MG, v. 29, n. 6, p. 1883-1886, 2000.

MAGALHÃES, H. R.; FARO, L. E.; CARDOSO, V. L.; PAZ, C. C. P.; CASSOLI, L. D.; MACHADO, P. F. Influência de fatores de ambiente sobre a contagem de células somáticas e sua relação com perdas na produção de leite de vacas da raça Holandesa. Revista Brasileira de Zootecnia, Viçosa, MG, v. 35, n. 2, p. 415-421, 2006.

MEYER, P. M.; MACHADO, P. F.; COLDEBELLA, A.; CASSOLI, L. D.; COELHO, K. O.; RODRIGUES, P. H. M. Fatores não-nutricionais e concentração de nitrogênio ureico no leite de vacas da raça Holandesa. Revista Brasileira de Zootecnia, Viçosa, MG, v. 35, n. 3, p. 1114-1121, 2006.

OLIVEIRA, U. V.; GALVÃO, G. S.; PAIXÃO, A. R. R.; MUNHOZ, A. D. Ocorrência, etiologia infecciosa e fatores de risco associados à mastite bovina na microrregião Itabuna-Ilhéus, Bahia. Revista Brasileira de Saúde e Produção Animal, Salvador, v. 11, n. 3, p. 630-640, 2010.
OLTNER, R.; WIKTORSSON, H. Urea concentrations of milk and blood as influenced by feeding varying amounts of protein and energy to dairy cows. Livestock Production Science, Champaign, v. 10, n. 5, p. 457-467, 1983.

PEREDA, J. A. O.; RODRIGUEZ, M. I. C.; ÁLVAREZ, L. F.; SANZ, M. L. G.; MINGUILLÓN, G. D. G. F.; PERALES, L. H.; CORTECERO, M. D. S. Tecnologia de alimentos. São Paulo: Artmed, 2005. 279 p.

PEREIRA, A. R.; MACHADO, P. F.; BARANCELLI, G.; SILVA, L. V. F. Contagem de células somáticas e qualidade do leite. Revista do Criador, São Paulo, v. 67, n. 807, p. 19-21, 1997.

PEREIRA, A. R.; MACHADO, P. F.; SARRÍES, G. A. Contagem de células somáticas e características produtivas de vacas da raça holandesa em lactação. Scientia Agricola, Piracicaba, v. 58, n. 4, p. 649-654, 2001.

PEREIRA, A. R.; PRADA E SILVA, L. F.; MOLON, L. K.; MACHADO, P. F.; BARANCELLI, G. Efeito do nível de células somáticas sobre os constituintes do leite I-gordura e proteína. Brazilian Journal of Veterinary Research and Animal Science, São Paulo, v. 36, n. 3, p. 429-433, 1999.

REIS, G. L.; ALVES, A. A.; LANA, A. M. Q.; COELHO, S. G.; SOUZA, M. R.; CERQUEIRA, M. M. O. P.; PENNA, C. F. A. M.; MENDES, E. D. M. Procedimentos de coleta de leite cru individual e sua relação com a composição físico-química e a contagem de células somáticas. Ciência Rural, Santa Maria, v. 37, n. 4, p. 1134-1138, 2007.

RIBAS, N. P.; HARTMANN, W.; MONARDES, H. G.; ANDRADE, U. V. C. Sólidos totais do leite em amostras de tanque nos estados do Paraná, Santa Catarina e São Paulo. Revista Brasileira de Zootecnia, Viçosa, MG, v. 33, n. 6, p. 2343-2350, 2004.

ROSA, D. C.; TRENTIN, J. M.; PESSOA, G. A.; SILVA, C. A. M.; RUBIN, M. I. B. Qualidade do leite em amostras individuais e de tanque de vacas leiteiras. Revista Arquivos do Instituto Biológico, São Paulo, v. 79, n. 4, p. 485-493, 2012.

SANTOS, M. V.; FONSECA, L. F. L. Estratégias para controle de mastite e melhoria da qualidade do leite. São Paulo: Manole, 2006. 314 p.

SHUSTER, D. E.; HARMON, R. J.; JACKSON, J. A.; HEMKEN, R. W. Suppression of milk production during endotoxin-induced mastitis. Journal of Dairy Science, Champaign, v. 74, n. 11, p. 3763-3774, 1991. 
SILVA, M. V. M.; NOGUEIRA, J. L.; PASSOS, C. C.; FERREIRA, A. O.; AMBRÓSIO, C. E. A mastite interferindo no padrão de qualidade do leite: uma preocupação necessária. Revista Científica Eletrônica de Medicina Veterinária, Garça, v. 8, n. 14, p. 1-10, 2010.

SILVA, N. M. A.; BASTOS, L. P. F.; OLIVEIRA, D. L. S.; OLIVEIRA, M. C. P. P.; FONSECA, L. M. Influence of somatic cell count and total bacterial counts of raw milk in cheese yield using small-scale methodology. Arquivos Brasileiros de Medicina Veterinária e Zootecnia, Belo Horizonte, v. 64, n. 5, p. 1367-1372, 2012.

SOUZA, R.; SANTOS, G. T.; VALLOTO, A. A.; SANTOS, A. L.; GASPARINO, E.; SILVA, D. C.; SANTOS, W. B. R. Revista Brasileira de Saúde e Produção Animal, Salvador, v. 11, n. 2, p. 484-495, 2010.

STATISTICAL ANALYSIS SYSTEM INSTITUTE SAS. Statistical Analysis System. SAS user's guide: statistics, version 9.0. Cary: SAS Institute, 2002.
ZAFALON, L. F.; NADER FILHO, A.; AMARAL, L. A. do; OLIVEIRA, J. V. de; RESENDE, F. D. de. Alterações da composição e da produção de leita oriundo de quartos mamários de vacas com e sem mastite subclínica de acordo com o estágio e o número de lactações. Arquivos do Instituto Biológico, São Paulo, v. 72, n. 4, p. 419-426, 2005.

ZANELA, M. B.; FISCHER, V.; RIBEIRO, M. E. R.; STUMPF JUNIOR, W.; ZANELA, C.; MARQUES, L. T.; MARTINS, P. R. G. Qualidade do leite em sistemas de produção na região Sul do Rio Grande do Sul. Pesquisa Agropecuária Brasileira, Brasília, v. 41, n. 1, p. 153-159, 2006.

ZHANG, L.; BOEREN, S.; VAN HOOIJDONK, A. C. M.; VERVOORT, J. M.; HETTINGA, K. A. A proteomic perspective on the changes in milk proteins due to high somatic cell count. Journal Dairy Science, Champaign, v. 98 , n. 8 , p. $5339-5351,2015$. 